\title{
Conceptual Metaphor of Anger Emotion in Grunge Musician's Song Lyrics
}

\author{
Gema Febriansyah \\ English Education Department \\ Masoem University \\ Indonesia \\ gema.febrian@gmail.com
}

Citation: Febriansyah, Gema. (2020). Conceptual metaphor of anger emotion in grunge musician's song lyrics. Notion: Journal of Linguistics, Literature, and Culture, Vol 2(1), p. 36-41.

DOI: http://doi.org/10.12928/notion.v2i1.1026

\begin{tabular}{|c|c|}
\hline Article Info & ABSTRACT \\
\hline $\begin{array}{l}\text { Article History } \\
\text { - Article Received } \\
30^{\text {th }} \text { August } 2019 \\
\text { - Article Accepted } \\
27^{\text {th }} \text { April } 2020 \\
\text { Keywords } \\
\text { Conceptual metaphor } \\
\text { Anger emotion } \\
\text { Emotion concepts } \\
\text { Image schemas } \\
\text { Cognitive semantics }\end{array}$ & $\begin{array}{l}\text { This journal is entitled "Conceptual Metaphor of Anger Emotion in Grunge } \\
\text { Musician's Song Lyrics". The objective of this study is to analyze and describe } \\
\text { conceptual metaphors of anger emotion that Grunge Musicians used in their song } \\
\text { lyrics and to analyze and describe the image schema formed in conceptual metaphor } \\
\text { of anger emotion. The data are taken from the lyrics of grunge musicians based on } \\
\text { the Rolling stones magazine about the best grunge musicians all the time. The } \\
\text { research uses a qualitative method since the data collected are in the form of words } \\
\text { rather than numbers and it is conducted based on the conceptual metaphor theory } \\
\text { and emotion concept theory from cognitive semantics study. The result of this } \\
\text { research shows that the conceptual metaphor of anger emotion mostly used by } \\
\text { grunge musicians are ANGER IS FIRE, ANGER IS AN OPPONENT IN A } \\
\text { STRUGGLE, ANGER IS A NATURAL FORCE, and ANGER IS A HOT FLUID } \\
\text { IN CONTAINER. The image schema that found in conceptual metaphor of anger } \\
\text { emotion is FORCE SCHEMA and CONTAINMENT SCHEMA. }\end{array}$ \\
\hline
\end{tabular}




\section{INTRODUCTION}

Metaphor and emotion appear in various shapes of language. Mark Johnson, as a cognitive semanticist, said the experiences and perceptions that exist in our mind will form the language itself so that the concept of metaphor and emotion will appear in the different types of language expressions that we used. One of the language expressions that we used is when we create a song lyric. Many song writers used conceptual metaphor to convey their emotion to their listeners. In the cognitive linguistic view, Kövecses[1]41 says metaphor is defined as understanding one conceptual domain in terms of another conceptual domain. A conceptual metaphor consists of two conceptual domains, source domain and target domain. The conceptual domain from which we draw metaphorical expressions to understand another conceptual domain is called source domain, while the target domain is the domain that we try to understand through the use of the source. Image schemas also play an important role in metaphor. Lakoff and Johnson[2] analyze metaphors as mappings of conceptual structure from one domain to the source domain and to another the target domain. Lakoff[3] argues that image schematic structure is preserved in the metaphorical mapping from a source domain to a target domain, provided it is consistent with already existing image schematic structure in the target domain. In his book[4] The Body in the Mind, Mark Johnson proposed that embodied experience gives rise to image schemas within the conceptual system. Image schemas derive from sensory and perceptual experience as we interact with and move about in the world. In addition to metaphor this research also deals with emotion, based on Kovecses[5] study about emotion, he mentioned about the relation between emotion and metaphor. To understand about that relation, firstly we have to know about the scope of that things. The issue of the scope of emotion metaphors has been examined by Kövecses[6]. The results of the study help us understand whether people comprehend emotion concepts in a unique way, which is by using the source domains that are specific to emotion concepts or by employing the source domains that are also used in the structuring of non-emotional concepts. In this research, the writer uses grunge music as data, because grunge music has a unique factor that make this data interesting. Many experts say that grunge music born in Seattle US. This music is a part of the alternative rock, which grunge itself is a type of music that has a delivery meaning through the expressive lyrics because their lyrics also has its own distinctive character. Catherine Strong, as a music researcher, argue that lyrically grunge is also very different to other successful music of the time. The background of this research is about the metaphor and emotion contained in the song lyrics of grunge musicians, therefore it is necessary to the writer to do a research to unravel the emotion concept depiction through metaphors in the song lyrics of grunge musicians. Based on these reasons the writer does research on the metaphor and emotion, especially metaphors of anger emotion with cognitive semantics approach.

\section{LITERATURE REVIEW}

\section{a. Theoretical Background}

This research is a cognitive semantic study. The writer takes some theories that become the main reference for this research. This research discusses about metaphors of anger emotion in grunge musician's song lyrics. There are two main problems in this research that are the conceptual metaphors of anger emotion that Grunge Musicians used in their song lyrics and the image schema formed in conceptual metaphor of anger emotion.

There are two grand theories that used in this research, the first theory is proposed by Lakoff and Johnson[2] stating that "the essence of metaphor is understanding and experiencing one kind of thing in terms of another". This theory is strengthened by Kovesces[1] who states that "conceptual metaphors is defined as understanding one conceptual domain in terms of another conceptual domain", and to analyze the image schema the writer used the theory that proposed by Johnson. The second theory is proposed by Kovecses[1]. The general conclusion drawn by Kövecses is that the majority of the source domains associated with emotion concepts are not specific to emotion concepts, but have a wider scope of application. 
"Indeed, we have found that most of the source domains of emotion concepts have a scope of application that extends beyond the domain of emotion. These non-specific source domains are parts of very general metaphorical mappings whose range of application covers large portions of our conceptual system. This has the important theoretical implication that, at least in cases like the domain of emotion, we do not understand abstract domains in unique ways, that is, by making use of a set of metaphors specific to a given abstract domain. Instead we seem to build up abstract domain from "conceptual materials" that we make use of in other parts of our conceptual system as well. "

In addition to that grand theory, the writer used several supported theories to substantiate the argument of this research. That theories are proposed in some Kovecses' works[5][6][8][9], Lakoff[3], Johnson[4], Talmy[12], and also the theory about grunge music by Strong[10].

\section{b. Research Question}

As mentioned before, this research deals with metaphors of anger and sadness emotion. By understanding of significance of the issue, the main problems that must be analyzed in this research can be seen as follows:

1) What are the conceptual metaphors of anger emotion that Grunge Musicians used in their song lyrics?

2) What are the image schema formed in conceptual metaphor of anger and sadness emotion?

\section{METHODOLOGY}

In this research, the writer applies descriptive qualitative method which means the description or the condition of such phenomena will be the issue that the writer concern about. Qualitative research explores question such as what, why and how, rather than how many and how much, it is primarily concerned with meaning rather that measuring. As it is known in the field of humanities and arts, researchers cannot deal with exact numbers, therefore they will explore more on the comprehensive condition rather than the exact measurements. He also mentioned that qualitative research sometimes described as cultural research because the focus is on the relationship between people and/ or between people and products, services or brands within a specific cultural context. There are three steps of qualitative research method. Those are collecting the data, analysis, and interpretation that researchers propose for their studies[11].

\section{a. Data Source}

The data used in this research is taken from the song lyrics of grunge musicians. Grunge is genre of rock music that flourished in the late 1980s and early '90s. The term grunge was first used to describe the murky-guitar bands (most notably Nirvana and Pearl Jam) that emerged from Seattle in the late 1980s as a bridge between mainstream 1980s heavy metal-hard rock and postpunk alternative rock. The early grunge movement revolved around Seattle's independent record label Sub Pop and that region's underground music scene. By the early 1990s its popularity had spread, with grunge bands appearing in California, then emerging in other parts of the United States and in Australia, building strong followings and signing major record deals.

According to Strong[10], she argue that "Grunge will be defined here as a musical genre and a cultural center that existed in the late 1980s and early 1990s, with associated fashions and ideologies, as well as political and musical alliances." She also argues about the lyrical of grunge musicians, according to her the grunge song lyric is different with other music genre. She said that "Lyrically grunge was also very different to other successful music of the time. With respect to its progenitors, punk and metal, grunge did not have explicit political lyrical content to the same extent as punk, nor the hedonistic ('sex, drugs and rock and roll') or apocalyptic vision of metal lyricists. When grunge dealt with 'love', the songs tended to be about failed, boring, doomed or destructive relationships (for example, the Pearl Jam song 'Black'). Songs were more likely to be about more generalized negative experiences or feelings, sung in a collective rather than individual voice".

As we know, there are many of grunge musicians that emerged and successful at the time. In this research, the writer restricted the musicians that chosen to be the data. The biggest music magazine in the world, Rolling Stone Magazine, released an article about grunge music in 2012. They make a poll to their readers about the best grunge albums of all time. Based on that article, the writer chose the bands and albums that according to Rolling Stone Magazine are the best band and album of Grunge music to be the data in this research. The bands and albums that chosen to be data are:

1) Pearl Jam (Album: “Ten" and "Vs") 
2) Nirvana (Album: "Nevermind", "Bleach", and "In Utero")

3) Alice in Chains (Album: "Dirt")

4) Soundgarden (Album: "Superunknown" and "Badmotorfinger")

5) Temple of the Dog (Album: "Temple of the Dog")

6) Mudhoney (Album: "Superfuzz Bigmuff Plus Early Singles")

\section{b. Data Collection tools and Procedures}

In line with Cresswell theory[11], the first step of this research is collecting the data. The data are taken from Grunge Musician's song lyrics. It is limited by the words or phrase contain conceptual metaphor of anger and sadness emotion.

The technique of data collecting will be as follows:

1) Selecting the Grunge Musicians based on Rolling Stones Magazine article about best grunge album all the time.

2) Collecting the Grunge Musician's song lyrics contain conceptual metaphors of anger emotion.

3) Classifying the data according to metaphor theory and emotion theory.

4) Analyzing the data based on the theory that the writer used.

After collecting all the data, the writer will analyze the data based on the theory. The technique of analyze the data will be as follows:

1) The writer reads the whole song lyrics for understanding the context.

2) The writer breaks up the song lyrics into the sentence or phrase contains conceptual metaphor of emotions.

3) The writer classifies the data into types of conceptual metaphor anger emotion.

4) The writer describes the reason why the data included into conceptual metaphor of anger emotion.

5) The writer describes the metaphorical mapping of the data.

6) The writer describes about why the data included into image schemas.

\section{RESULT AND DISCUSSION}

As the writer mentioned earlier this research deals with the type of conceptual metaphor of anger emotion and the image schema formed in conceptual metaphor of anger emotion. Based on this research, the writer finds six data included into the FORCE SCHEMA which are divided into four types of conceptual metaphor of anger and two data included into CONTAINMENT SCHEMA which are consist of one type of conceptual metaphor of anger.

\section{a. Force Schema}

In this research, the writer finds four types of conceptual metaphor of anger emotion in grunge musician's song lyrics included into FORCE SCHEMA that are ANGER IS FIRE, ANGER IS AN OPPONENT IN A STRUGGLE, ANGER IS CAPTIVE ANIMAL, and ANGER IS A NATURAL FORCE.

\begin{tabular}{|c|c|c|}
\hline Data & Lyric by & Metaphors \\
\hline $\begin{array}{l}\text { She'll come back as fire, to } \\
\text { burn all the liars }\end{array}$ & $\begin{array}{l}\text { Nirvana, "In } \\
\text { Utero" }\end{array}$ & $\begin{array}{l}\text { ANGER IS } \\
\text { FIRE }\end{array}$ \\
\hline Burning on the angry chair & $\begin{array}{l}\text { Alice in Chain, } \\
\text { "Dirt" }\end{array}$ & $\begin{array}{l}\text { ANGER IS } \\
\text { FIRE }\end{array}$ \\
\hline $\begin{array}{l}\text { Trying to take my } \\
\text { Indignance away from me }\end{array}$ & $\begin{array}{l}\text { Soundgarden, } \\
\text { "Badmotorfinger" }\end{array}$ & $\begin{array}{c}\text { ANGER IS } \\
\text { AN } \\
\text { OPPONENT } \\
\text { IN A } \\
\text { STRUGGLE }\end{array}$ \\
\hline No way to fight the anger & $\begin{array}{c}\text { Mudhoney } \\
\text { "Every Good Boy } \\
\text { Deserves Fudge" }\end{array}$ & $\begin{array}{c}\text { ANGER IS } \\
\text { AN } \\
\text { OPPONENT } \\
\text { IN A } \\
\text { STRUGGLE }\end{array}$ \\
\hline I'll hold the pain, release me & Pearl Jam, "Ten” & $\begin{array}{l}\text { ANGER IS A } \\
\text { CAPTIVE } \\
\text { ANIMAL }\end{array}$ \\
\hline A great wave of anger & Nirvana & $\begin{array}{c}\text { ANGER IS A } \\
\text { NATURAL } \\
\text { FORCE }\end{array}$ \\
\hline
\end{tabular}

The song lyrics above is included into the kind of conceptual metaphor ANGER IS FIRE, ANGER IS AN OPPONENT IN A STRUGGLE, ANGER IS CAPTIVE ANIMAL, and ANGER IS A NATURAL FORCE. This can be seen from the selection of words and meanings in the sentence. The choice of phrase come back as fire and to burn all the liars, burning on, trying to take my indignance, fight and anger, hold the pain, 
grunge musician's song lyrics included into CONTAINMENT SCHEMA that is ANGER IS A HOT FLUID IN CONTAINER.

\begin{tabular}{ccc}
\hline & Data & Metaphors \\
\hline $\begin{array}{c}\text { A second } \\
\text { chance he } \\
\text { hasn't calm, } \\
\text { but he is } \\
\text { boiling with } \\
\text { anger }\end{array}$ & $\begin{array}{c}\text { Lyric by Mudhoney, } \\
\text { Album Piece of } \\
\text { Cake }\end{array}$ & $\begin{array}{c}\text { ANGER IS A HOT } \\
\text { FLUID IN } \\
\text { CONTAINER. }\end{array}$ \\
$\begin{array}{c}\text { My milk is } \\
\text { your shit, It's } \\
\text { hard and } \\
\text { boiled }\end{array}$ & $\begin{array}{c}\text { Nirvana,Album } \\
\text { The Other }\end{array}$ & ANGER IS A HOT \\
\hline Table 3. Containment Schema's Data
\end{tabular}

The song lyric above is included into the kind of conceptual metaphor ANGER IS A HOT FLUID IN CONTAINER. This can be seen from the selection of words and meanings in the sentence. The choice of phrase he is boiling in the lyric shows the concept of hot fluid in container because the phrase he is boiling clearly mentioned about concept of hot fluid which described anger as a fluid and phrase anger clearly show the concept of anger emotion.

Like the writer mentioned above Conceptual metaphor has two domains, for example when we talk about anger in terms of hot fluid in container, the target domain is anger and the source domain is hot fluid. Source domain hot fluid in the data is represented through the phrase be is boiling which becomes a symbol of the hot fluid in the lyrics, meanwhile the target domain anger in the data is represented through the word anger.

Metaphorical mapping from the emotion concept above is a set of mapping from source domain and target domain. From the source domain and target domain interpretations above we can find the meaning between source and target. The used of the sentence "he is boiling with anger", and the expression be is boiling indicates the actor who boiled by anger and something that boiled because of the hot fluid, and the expression anger refers to what the song writer felt. This sentence gives us two constituent elements of hot fluid in container: the actor and be became boiled because of his anger. However, this sentence can be interpreted to be about anger, and the utterer of the sentence has in mind is not real actor but people who is angry and he became boiled because of his anger of this lyric is not a real boiled but just depiction of anger. 


\begin{tabular}{cc}
\hline $\begin{array}{c}\text { Source: Hot Fluid in } \\
\text { Container }\end{array}$ & Target: Anger \\
\hline the actor & angry people \\
He became boiled because & depiction of anger \\
of his anger & \\
\hline $\begin{array}{c}\text { Table 4. Metaphorical Mapping of ANGER IS A HOT FLUID } \\
\text { IN CONTAINER }\end{array}$
\end{tabular}

This is the systematic set of mappings, that characterize the anger is fire conceptual metaphor. It is the application of the hot fluid domain to the anger domain that provided the concept of anger with this particular structure or set of elements.

The lyrics above contains CONTAINMENT SCHEMA. The reason why this data included into CONTAINMENT SCHEMA is that the phrase boiling with anger liken anger with boiling which means anger is thought to be in a container because anger is considered a hot liquid. This is in line with what Mark Johnson said about CONTAINMENT SCHEMA that is containment something that boundary, enclosed area or volume, or excluded area or volume.

\section{CONCLUSION}

Based on the analysis, the writer may conclude that there are several fact findings regarding conceptual metaphor of anger emotion in Grunge musician's song lyrics. First, the writer found a number of conceptual metaphor of anger in the data. They are: ANGER IS FIRE, ANGER IS AN OPPONENT IN A STRUGGLE. ANGER IS A CAPTIVE ANIMAL, ANGER IS A NATURAL FORCE, and ANGER IS A HOT FLUID IN CONTAINER. All of type conceptual metaphor of anger emotion that found in this research has the same number of data except ANGER IS A CAPTIVE ANIMAL and ANGER IS A NATURAL FORCE that has only one data. Second, the writer found a number of image schema formed in conceptual metaphor of anger emotion in the data. They are: FORCE SCHEMA and CONTAINMENT SCHEMA. The most type shown up in the data is FORCE SCHEMA with consist of 6 data. The least image schema found in the data are CONTAINMENT SCHEMA in 2 data.

In general conclusion, the writer could found the similarities between grunge musician's lyrics in the data with the theory about grunge music by Catherine Strong. She argued that "Lyrically grunge was also very different to other successful music of the time......... When grunge dealt with 'love', the songs tended to be about failed, boring, doomed or destructive relationships (for example, the Pearl Jam song (Black'). Songs were more likely to be about more generalized negative experiences or feelings, sung in a collective rather than individual voice"[10]. this study shows how the different between lyrics of grunge musicians with the lyrics of other music genres. We can see the lyrics of grunge musicians in this data is very unique and contain many emotional lyrics, especially anger emotion. Finally, the uses of conceptual metaphor of anger and sadness emotion in this data produced very deep meanings. Nirvana band as one of the greatest grunge musicians all the time produced song lyrics with the most conceptual metaphor of anger emotion in the data.

\section{REFERENCES}

[1] Kövecses, Z. (2010). Metaphor. A practical introduction. New York: Oxford University Press.

[2] Lakoff, G. dan Johnson, M. (1980). Metaphor we live by. Chicago: The University of Chicago Press

[3] Lakoff, G. (1993). The contemporary theory of metaphor. In A. Ortney (Ed.). Metaphor and Thought $\left(2^{\text {nd }}\right.$ ed.), p. 2002-2051. Cambridge, MA: Cambridge University Press.

[4] Johnson, M. (1987). The body in the mind. The bodily basis of meaning, imagination, and reason. Chicago: The University of Chicago Press.

[5] Kövecses, Z. (2000). Metaphor and emotion. Cambridge: Cambridge University Press.

[6] Kövecses, Z. (2005). Metaphor in culture: Universality and variation. New York: Cambridge University Press

[7] Lakoff, G. (1987). Woman, fire, and dangerous things: What categories reveal about the mind. Chicago: University of Chicago Press

[8] Kövecses, Z. (2006). Language, mind, and culture: $A$ practical introduction. New York: Oxford University Press.

[9] Kövecses, Z. (1990). Emotion concepts: Metaphor and culture. Berlin and New York: Springer- Verlag.

[10]Strong, C. (2011). Grunge: Music and memory. Surrey: Ashgate Publishing Limited.

[11]Creswell J. W. (2014). Research design: Qualitative, quantitative, and mixed method approaches $\left(4^{\text {th }} \mathrm{Ed}\right)$. London: SAGE Publications Ltd.

[12]Talmy, L. (2000). Toward a cognitive semantics. Massachusetts: MIT Press. 